\title{
Russia and the Idea of Europe: A Study in Identity and International Relations
}

\author{
Iver B. Neumann \\ London: Routledge 2017 \\ 214 sider. ISBN 9781138182615
}

\author{
Omtalt af Gry Waagner Falkenstrøm [Ph.d.-studerende, Dansk Institut for \\ Internationale Studier (DIIS), grwf@diis.dk]
}

\begin{abstract}
Aktører i international politik handler til tider på baggrund af en meget kort historisk referenceramme. Tilsvarende er meget menings- og politikdannelse om EU's forhold til Rusland i dag formet af de konfliktnarrativer, som blev dominerende efter Ruslands annektering af Krim i 2014. Iver Neumanns Russia and the Idea of Europe står i stærk kontrast hertil og bidrager med et imponerende helikopterblik over århundreders rusisiske tænkning om forholdet til Europa. Denne 2. udgave af bogen udgives to årtier efter første version, og det markante skifte fra samarbejde mod konfrontation i Rusland-EU-politikken sætter i sig selv en interessant ramme for at læse eller genlæse bogen.
\end{abstract}

Gennem bogen illustrerer Neumann, hvordan diskursive kampe om Ruslands Europa-politik har været medskabere af ikke kun inden- og udenrigspolitiske handlingsrum, men også russisk identitet. Fokus ligger på de ofte modstridende italesættelser af den europæiske "anden", som russiske magthavere og deres opposition har benyttet til at legitimere deres forskellige politiske projekter. Efter en kort introduktion til Ruslands balancegang mellem øst og vest siden dannelsen af Kijevrus-riget omkring år 860, giver bogen sig i kast med det ambitiøse projekt at introducere læseren til 200 års russisk Europa-debat siden Napoleonskrigene og til i dag. Vi præsenteres for meningsdannere, der argumenterer for, at integration med Europa er afgørende for Ruslands økonomiske og teknologiske udvikling, og dem der ser det som Ruslands hellige pligt at redde et moralsk afsporet Vesteuropa. På den anden side er der fortalerne for russisk isolation og selvtilstrækkelighed.Vi præsenteres blandt andet for doktrinen for officiel nationalisme med parolerne autokrati, ortodoks religion og nationalfølelse, som tsarstaten adopterede som modsvar til de pro-europæiske decembristers oprør i 1825 . Et par kapitler senere forsøger slavisterne op mod den første Krim-krig i 1853 at ændre sammenligningsgrundlaget mellem Europa og Rusland fra den teknisk-økonomiske til den spirituelle sfære. Vi introduceres til nogle af socialisternes mange interne magtkampe og udviklingen af den totalitære sovjetstats meningsmonopol samt en række andre skelsættende begivenheder i udviklingen af den russiske stat og samfund. 
Formålet med Neumanns studier er at vise, hvordan Rusland historisk har bevæget sig i såkaldte "pendulbevægelser" mellem henholdsvis at omfavne og afvise tilhørsforholdet til Europa. Som en del af argumentationen illustrerer han, hvordan Perestrojka-tiden og Sovjetunionens kollaps medførte et nyt pendulsving i liberal og europæisk retning. Meget er sket i Rusland siden første udgave af Neumanns bog blev udgivet i 1996. I overensstemmelse med forfatterens argumentation har pendulet nu taget et sving væk fra halvfemsernes statslige Europa-optimisme og ind på en velkendt Europa/Vesten-kritisk vej. Efter Vladimir Putins genindsættelse på præsidentposten i 2012 indtog den russiske stat en markant modposition til det liberale Europa. Kort efter boostede krigen i Ukraine for alvor konfliktnarrativerne, hvori Europa (med EU som fremmeste repræsentant) ofte fremstilles som dekadent og ukristent, mens Rusland omvendt ses som garanten for de sande europæiske værdier.

Neumanns idéhistoriske tour de force giver interessant stof til eftertanke, når man i dag observerer nutidens russiske ideologiske og politiske projekter: Aleksandr Dugin og andre højreekstremes drøm om at genskabe det historiske Novorossija det nye Rusland - i Ukraines sydøstlige regioner samt oprettelsen af Den Eurasiske Økonomiske Union som kopi og østligt alternativ til EU kan nævnes som eksempler. Hvis man kigger på Putin-regimets flirt med højrenationale xenofobiske partier i Europa samt den hårde håndtering af især den interne liberale opposition, bringes de historiske dynamikker helt op på den nutidige politiske arena. Neumanns nedslag i nyere russisk historie drager på den måde interessante perspektiver fra fortidens værdidiskussioner til magtspillet omkring Putin i dag. Desværre er Neumanns bidrag til at forstå udviklingen mellem Europa/Vesten og Rusland under præsident Putin (ti sider). Det er en skam, for der er ingen tvivl om, at de idéhistoriske linjer, som føres op igennem både historiens og bogens lineære forløb, kunne have bibragt endnu flere interessante perspektiver til både Ruslands nutidige ambivalente forhold til de europæiske naboer og de interne kampe om at omskrive Ruslands historie $\mathrm{i}$ Putin-regimets favør. Ruslands annektering af Krim, som må ses som den absolutte "smoking gun" i Ruslands temporære brud med drømmen om europæisk integration, introduceres blot flygtigt. Det betyder, at bogen ikke analyserer, hvad denne største nutidige konflikt på det europæiske kontinent betyder for forholdet mellem Rusland og Europa samt for de interne ideologiske magtkampe i Rusland. Det er i min optik en tabt mulighed for at bidrage med substantielle analytiske betragtninger af et politisk internationalt klima, som ofte analyseres uden rod i det idéhistoriske fundament, som Neumann ellers så vigtigt påviser relevansen af. 2. udgave af Russia and the Idea of Europe skal derfor fortsat primært ses som en analyse af forskellige stridende røster, der har formet århundreders idéhistoriske udvikling i Rusland - og ikke som en samtidsanalyse af det politiske klima siden Putins magtovertagelse. Det skal derfor understreges, at Neumanns store akademiske bidrag til konceptualiseringen af Europa som Ruslands "definerende anden" fortsat gør bogen til et vigtigt bidrag for læsere med interesse i skabelsen af identitet i international politik. 


\section{6 | GRY WAAGNER FALKENSTRØM}

I en tid hvor mange Ruslandsanalyser skrives uden henvisning til russiske kilder, er bogen en yderst aktuel genintroduktion til nogle af de sidste århundreders toneangivende russiske tænkere. Gennem korte og lange citater ser vi selv, hvordan Kirejevskij i 1830'erne beskriver forholdet mellem Rusland og Europa, som var det delt af en kinesisk mur (s. 22), og udenrigsminister Gortjakov i 1876 ser Rusland som »et stort, magtesløst land» (s. 49), mens Solovjov i 1905 fremhæver det russiske folks "mørke og grundlæggende magt« (s. 62). Trotskij drømmer om »et holdbart socialistisk diktatur" (s. 75), mens et romantisk nationalistisk manifest fra 1970'erne hævder, at "ondskabens ånd, med dets horn skjult under en Beatles frisure, prøver på at udføre dets fordærvelige og opløsende aktivitet« (s. 128) - en malerisk reference til tidens stigende vestlige indflydelse. Ordene er store, og billederne er stærke. De historiske personer diskuterer med hinanden og beriger læseren med interessante nedslagspunkter i den store debat om Ruslands rolle i Europa. Den til tider mangelfulde legimitation for kildernes centrale position i debatten svækker dog bogens læsevenlighed. En gennemskrivning, hvor forfatteren tog læseren lidt mere ved hånden, ville derfor have haft potentiale til at gøre bogen relevant for et bredere publikum uden forudgående kendskab til russisk politik og historie.

Der er dog overordnet set ingen tvivl om aktualiteten $i$ at genudgive Russia and the Idea of Europe. Mange iagttagere af nutidig europæisk politik besidder utvivlsomt et brændende ønske om en bedre forståelse for de nuancer i det russiske sociale og politiske landskab, som fremstår så uforståelige, endda mystiske, for mange i Vesten. Bogen bidrager med en bred vifte af sådanne nuancer. Som det var tilfældet i 1996-udgaven, benytter Neumann også denne gang chancen til at spå om fremtiden. Indlednings- og afslutningsvist understreger han den strukturelle karakter af bogens argument med en forudsigelse om, at pendulet i nær fremtid vil svinge fra den nutidige dominerende xenofobiske stats-nationalisme over i en mere pro-vestlig retning. Kun den kommende årrækkes politiske udvikling internt i Rusland vil give os svar på, om »Neumann-pendulets« forklaringskraft forsat vil holde stik. 